\title{
EFEKTIVITAS PEMBERIAN MAKANAN TAMBAHAN DENGAN KONSEP EMPAT BINTANG TERHADAP KENAIKAN BERAT BADAN BALITA GIZI BURUK DI POSYANDU WILAYAH PUSKESMAS NGAWEN KABUPATEN KLATEN
}

\author{
Anik Kurniawati, Endang Suwanti \\ Kementerian Kesehatan Politeknik Kesehatan Surakarta Jurusan Kebidanan
}

\begin{abstract}
Toddler, PMBA, Malnutrition. Background, Klaten district shows the incidence of malnutrition as many as 479 infants and less than 2,890 children under five nutrition, one in Ngawen health ceter in Candirejo village has 3 malnourished children under five and 21 toddler less nutrition, the participation rate of toddler to posyandu also still below target that is 80, 35\%\% while the weight gain rate of children under 5 years old is still under the target of 72,75\%, and Mayungan Village there are 7 children under five with malnutrition status and 37 under fives with less nutritional status. While the rate of weight gain that comes to be weighed to posyandu is still under the target of $58.54 \%$. Some mothers said that children underweight and malnutrition caused by toddlers difficult to eat. Some of the problems that many occur at the beginning of infant feeding is the lack of food variations given by parents, especially fruit, vegetables and animal side dishes. The purpose, to determine the effectiveness of additional food description with the concept of four stars to increase weight toddler malnutrition in Posyandu area Ngawen Puskesmas Klaten District. The research hypothesis, supplementary food queue with the concept of four stars effectively increase the weight of malnutrition toddler at Posyandu of Puskesmas Ngawen Region, Klaten Regency. Research Method, This research type is experiment, with approach of quasi ekapeiment with design of Nonequivalent Control Group Design. Target population in this research is all toddler malnutrition in posyandu of puskesmas ngawen area counted 24 toddler. Sampling technique in this study is purposive sampling, toddlers taken into the sample is a toddler who is not getting another treatment for 18 toddler. Data analysis using independent $t$ test test hypothesis test using Anava Friedman test. The results showed normal distributed data. Independent test of t-Test shows sig value $(0.000)<0,05$. This means that there are significant differences in body weight of pre-test and body weight of post test with correlation of 0.995. Hypothesis test results show data that sig value (0.008) <0.05 supplementary feeding with the concept of 4 stars effectively increase the weight of children under five with malnutrition in posyandu of puskesmas Ngawen subdistrict Ngawen Sub-district of Klaten Regency.
\end{abstract}

Keywords: Toddler, PMBA, Malnutrition

Abstrak: Balita, PMBA, Gizi Buruk. Latar Belakang, kabupaten Klaten menunjukkan kejadian gizi buruk sebanyak 479 balita dan gizi kurang 2.890 balita, salah satunya di puskesmas Ngawen yaitu di desa Candirejo memiliki 3 balita gizi buruk dan 21 balita gizi kurang, tingkat partisipasi balita ke posyandu juga masih dibawah target yaitu $80,35 \% \%$ sedangkan tingkat kenaikan berat badan balita yang datang ke posyandu 
(N/D) juga masih dibawah target yaitu 72,75\%, serta Desa Mayungan masih terdapat 7 balita dengan status gizi buruk dan 37 balita dengan status gizi kurang. Sedangkan tingkat kenaikan berat badan balita yang datang ditimbang ke posyandu masih dibawah target yaitu 58,54\%. Sebagian ibu mengatakan bahwa balita mengalami gizi kurang dan gizi buruk diakibatkan balita susah makan. Beberapa permasalahan yang banyak terjadi pada saat permulaan pemberian makanan tambahan bayi yaitu kurangnya variasi makan yang diberikan orang tua, utamanya buah, sayur dan lauk hewani. Tujuan untuk mengetahui efektifitas pemerian makanan tambahan dengan konsep empat bintang terhadap kenaikan berat badan balita gizi buruk di Posyandu wilayah Puskesmas Ngawen Kabupaten Klaten. Jenis penelitian ini adalah eksperiment, dengan pendekatan quasi ekapeiment dengan desain Nonequivalent Control Group Design. Populasi target dalam penelitian ini adalah seluruh balita gizi buruk di posyandu wilayah puskesmas ngawen sebanyak 24 balita. Teknik pengambilan sampel dalam penelitian ini adalah purposive sampling, balita yang diambil menjadi sampel adalah balita yang sedang tidak mendapatkan treatment lain sebesar 18 balita. Analisis data menngunakan uji independent t-test an uji hipotesis menggunakan uji Anava Friedman. Hasil penelitian menunjukkan data berdistribusi normal. Uji independen t-Test menunjukkan nilai sig $(0,000)<0,05$. Artinya terdapat perbedaan yang signifikan berat badan balita pre test dan berat badan balita post test dengan nilai correlation sebesar 0,995. Hasil uji hipotesis menunjukkan data bahwa nilai sig $(0.008)<0,05$ pemberian makanan tambahan dengan konssep 4 bintang efektif menaikkan berat badan balita dengan gizi buruk di posyandu wilayah puskesmas Ngawen kecamatan Ngawen Kabupaten Klaten.

Kata Kunci: Balita, PMBA, Gizi Buruk

\section{PENDAHULUAN}

Masalah gizi terjadi di setiap siklus kehidupan, dimulai sejak dalam kandungan (janin), bayi, anak, dewasa, dan usia lanjut. Periode balita merupakan masa kritis karena pada saat itu merupakan masa emas untuk pertumbuhan dan perkembangan balita, oleh karena itu gizi pada masa balita perlu diperhatikan. Gangguan gizi yang terjadi pada periode ini bersifat permanen, tidak dapat dipulihkan walaupun kebutuhan gizi pada masa selanjutnya terpenuhi.

Permasalahan gizi dipengaruhi oleh penyebab langsung dan tidak langsung. Penyebab langsung yaitu masukan zat gizi dan penyakit infeksi, sedangkan penyebab tidak langsung antara lain ketahanan pangan dalam rumah tangga, pola pengasuhan anak, pelayanan kesehatan, dan kesehatan lingkungan. Ketahanan pangan dalam rumah tangga dan pola pengasuhan anak dipengaruhi oleh kondisi sosioekonomi dan pengetahuan ibu tentang gizi (Istiono dkk, 2009). Pola pengasuhan anak termasuk dalam pemberian makanan tambahan pada balita.

Pada tahun 2014 WHO memperirakan terdapat 161 juta balita mengalami masalah gizi, sedangkan hasil Riskesdas Tahun 2013 menunjukkan prevalensi gizi kurang dan gizi buruk mengalami peningkatan (Riskesdas, 2013). Ditjen Gizi Kementerian kesehatan telah banyak mengeluarkan program dan kebijakan dalam mengupayakan perbaikan gizi masyrakat, salah satunya dengan 
pemberian makanan pada bayi dan balita (PMBA) dengan konsep 4 bintang yang diterapkan pada bayi dan anak usia sampai 24 bulan, namun program tersebut masih banyak yang belum mengetahuinya. Studi pendahuluan yang dilakukan di Kabupaten Klaten menunjukkan kejadian gizi buruk sebanyak 479 balita dan gizi kurang 2.890 balita, salah satunya di puskesmas Ngawen yang memiliki balita gizi buruk sebanyak 24 balita, tingkat partisipasi balita ke posyandu juga masih dibawah target yaitu $80,19 \%$ sedangkan tingkat kenaikan berat badan balita yang datang ke posyandu (N/D) juga masih dibawah target yaitu $72,77 \%$. Beberapa permasalahan yang banyak terjadi pada saat permulaan pemberian makanan tambahan bayi yaitu kurangnya variasi makan yang diberikan orang tua, utamanya buah, sayur dan lauk hewani, standar keluarga sadar gizi apabila keluarga dapat mengonsumsi lauk hewani minimal 3 kali sehari. Kecamatan Ngawen memiliki warga masyarakat dengan tingkat perekonomian pada kelompok pra sejahtera dan sejahtera satu sekitar $30 \%$ dari keseluruhan penduduk, sehingga hai ini membuat masyarakat kurang mampu menyediakan makanan yang bervariasi dan mengonsumsi makanan dengan konsep 4 bintang yang terdiri dari makanan pokok, kacang-kacangan, lauk hewani dan sayur atau buah-buahan. Balita gizi kurang dan buruk seharusnya mendapatkan makanan tambahan 4 bintang sesuai dengan usianya, dalam kondisi tertentu pemberian makanan yang sesuai dengan 4 bintang sulit diberikan, antara lain dalam kondisi ekonomi keluarga yang kurang atau pengetahuan ibu yang kurang.

Penelitian ini bertujuan untuk mengetahui efektifitas pemberian makanan tambahan pada balita dengan konsep 4 bintang terhadap kenaikan berat badan balita gizi buruk di posyandu wilayah puskesmas Ngawen Kecamatan Ngawen Kabupaten Klaten

\section{METODE PENELITIAN}

Jenis penelitian ini adalah eksperiment, dengan pendekatan quasi ekapeiment dengan desain pretest-posstest experimental non control group design. Pada penelitian ini, terdapat satu kelompok perlakuan dengan satu kelompok kontrol. Penelitian di dilakukan diposyandu wilayah Puskesmas Ngawen Kabupaten Klaten.

Populasi alam penelitian ini adalah seluruh balita di kecamatan Ngawen sedangkan populasi terjangkau adalah balita yang megalami gizi buruk sebanyak 24 balita. Teknik pengambilan sampel dengan purposve sampling. Balita yang diambil adalah balita yang tidak sedang mendapatkan treatment apapun baik dari puskesmas ataupun program yang lain.

Variabel bebas dalam penelitian ini adalah pemberian makanan tambahan dengan konsep empat bintang, yaitu memberikan makanan tambahan pada balita dengan status gizi kurang dan buruk dengan komponen lengkap meliputi protein hewani, makanan pokok, kacangkacangan dan sayur serta buah, yang diberikan sehari 3 kali serta dalam 1 minggu diberikan 3 kali dalam periode waktu selama 2 bulan, sedangkan variabel terikat adalah kenaikan berat badan balita yaitu keadaan hasil penimbangan berat badan balita pada bulan pertama dan bulan kedua setelah dilakukan perlakuan. Balita dengan gizi buruk dilakukan penimbangan terlebih dahulu kemudian diberikan makanan tambahan dengan konsep 4 bintang 3 kali sehari dalam satu minggu 
diberian 3 hari dan periode waktu pemberian selama 2 bulan, kemudian dilakukan penimbangan yang kedua untuk menilai peningkatan berat badan balita. Instrument penelitian ini berupa lembar observasi. Lembar observasi terdiri atas identitas dan karakteristik responden, serta hasil observasi yang dilakukan sendiri oleh responden sesuai dengan yang dirasakannya sebelum dan setelah perlakuan. Status gizi diukur menggunakan standar baku NCHS, dalam hal ini pengukuran status gizi menggunakan penilian indeks antropometri diukur dengan $\mathrm{BB} / \mathrm{U}$ dan TB/U.kenaikan berat badan balita gizi buruk diukur dengan menggunakan timbangan yang sebelumnya telah dilakukn uji terra di badan metrologi. Analisis data univariat dilakukan untuk mendeskripsikan karakteristik responden dan data sebelum dilakuka uji hipotesis, sedangkan analisis bivariat dilakukan uji normalitas uji saphiro Wilk dengan hasil nilai signifikansi $>0,05$ sehingga sehingga dapat disimpulkan kedua variable tersebut berdistribusi normal. Selanjutanya untuk membandingkan dua kelompok, dilakukan uji beda menggunakan independen t-Test. Sedangkan untuk menguji hipotesis penelitian, menggunakan uji Anava, dengan uji alternative Friedman

\section{HASIL PENELITIAN}

\section{Karakteristik Responden}

\section{a. Pendapatan}

Tabel 1

Karakteristik Ibu Balita Berdasarkan Pendapatan

\begin{tabular}{lcc}
\hline Pendapatan & Frekuensi & Persen \\
\hline Gakin & 16 & 88.9 \\
Non Gakin & 2 & 11.1 \\
\hline Total & 18 & 100.0 \\
\hline
\end{tabular}

Berdasarkan tabel diatas karakteristik ibu balita berdasarkan pendapatan menunjukkan responden gakin sebanyak 16 responden $(88,9 \%)$ dan non gakin sebanyak 2 responden $(11,1 \%)$. Sehingga dapat disimpulkan bahwa responden terbanyak merupakan keluarga miskin.

\section{b. Pendidikan}

Tabel 2

Karakteristik Ibu Balita Berdasarkan Pendidikan

\begin{tabular}{|c|c|c|}
\hline Pendidikan & Frekuensi & Persen \\
\hline SD & 1 & 5.6 \\
\hline SMA & 12 & 66.7 \\
\hline SMP & 5 & 27.8 \\
\hline Total & 18 & 100.0 \\
\hline
\end{tabular}

menunjukkan karakteristik ibu balita berdasarkan pendidikan terakhir SD sebanyak 1 responden $(5,6 \%)$, SMA sebanyak 12 responden $(66,7 \%)$ dan SMP Sebanyak 5 responden $(27,8 \%)$. Sehingga dapat disimpulkan responden terbanyak dengan pendidikan terakhir SMA.

\section{c. Jenis Kelamin Balita Tabel 3}

Karakteristik Balita Berdasarkan Jenis Kelamin

\begin{tabular}{|c|c|c|}
\hline Jenis Kelamin & Frekuensi & Persen \\
\hline Laki-Laki & 8 & 44.4 \\
\hline Perempuan & 10 & 55.6 \\
\hline Total & 18 & 100.0 \\
\hline
\end{tabular}

karakteristik balita berdasarkan jenis kelamin menunjukkan balita dengan jenis kelamin laki-laki sebanyak 8 responden $(44,4 \%)$ dan perempuan sebanyak 10 responden $(55,6 \%)$. Sehingga dapat disimpulkan responden terbanyak dengan Janis kelamin perempuan. 


\section{d. Usia Balita}

\section{Tabel 4}

Karakteristik Balita Berdasarkan Usia

\begin{tabular}{lcc}
\hline Usia (Bulan) & Frekuensi & Persen \\
\hline $11-20$ & 5 & 28 \\
$21-30$ & 6 & 33 \\
$31-40$ & 2 & 11.1 \\
$41-50$ & 4 & 22 \\
$51-60$ & 1 & 5.6 \\
\hline Total & 18 & 100.0 \\
\hline & Berdasarkan & table
\end{tabular}

karakteristik balita berdasarkan usia menunjukkan balita dengan usia 11-20 bulan sebanyak 5 responden (28\%), 21-30 bulan sebanyak 6 responden (33\%), 31-40 bulan sebanyak 2 responden $(11,1 \%), 41$ 50 bulan sebanyak 4 responden $(22 \%)$ dan 51-60 bulan sebanyak 1 responden $(5,6 \%)$ sehingga dapat disimpulkan responden terbanyak dengan usia 21-30 bulan.

\section{Analisis Univariat}

\section{a. Berat Badan Balita Pre Test} Tabel 5

Berat Badan Balita Pre Test

\begin{tabular}{|c|c|c|}
\hline Berat badan & Frekuensi & Persen \\
\hline $5-6$ & 5 & 28 \\
\hline 7-8 & 5 & 28 \\
\hline $9-10$ & 6 & 33 \\
\hline $11-12$ & 2 & 11 \\
\hline Total & 18 & 100.0 \\
\hline
\end{tabular}

badan balita pre test menunjukkan balita dengan berat 5-6 kg sebanyak 5 responden (28\%), 7-8 kg sebanyak 5 responden (28\%), 9-10 kg sebanyak 6 responden (33\%) dan 11-12 sebanyak 2 responden (11\%) sehingga dapat disimpulkan bahwa responden terbanyak dengan berat 9-10 $\mathrm{kg}$. b. Berat Badan Balita Pos Test

Tabel 6

Berat Badan Balita Pos Test

\begin{tabular}{|c|c|c|}
\hline Berat Badan & Frekuensi & Persen \\
\hline $5-6$ & 5 & 28 \\
\hline 7-8 & 5 & 28 \\
\hline $9-10$ & 6 & 33 \\
\hline $11-12$ & 2 & 11 \\
\hline Total & 18 & 100.0 \\
\hline
\end{tabular}

badan balita pre test menunjukkan balita dengan berat 5-6 kg sebanyak 5 responden (28\%), 7-8 kg sebanyak 5 responden (28\%), 9-10 kg sebanyak 6 responden (33\%) dan 11-12 sebanyak 2 responden (11\%) sehingga dapat disimpulkan bahwa responden terbanyak dengan berat 9-10 $\mathrm{kg}$.

\section{Analsisi Bivariat}

Sebelum menentukan analisis data yang digunakan maka terlebih dahulu dilakukan uji normalitas. Uji normalitas yang digunakan dalam penelitian ini adalah Shapiro Wilk karena jumlah responden < 50. Berdasarkan hasil uji normalitas diperoleh hasil sebagai berikut:

\section{Tabel 7}

Hasil Uji Normalitas Shapiro Wilk

\begin{tabular}{lccc}
\hline Variabel & Sig & Standar Sig & Ket \\
\hline Pre Test & 0.830 & 0,05 & Normal \\
Post Test & 0.743 & 0,05 & Normal \\
\hline
\end{tabular}

Berdasarkan hasil uji normalitas diatas menunjukkan kedua variable memiliki nilai sig. $>0,05$ sehingga dapat disimpulkan kedua variable tersebut berdistribusi normal. Selanjutanya untuk membandingkan dua kelompok, dilakukan uji beda menggunakan independen t-Test dan diperoleh hasil sebagai berikut: 
Tabel 8

Hasil Uji independen t-Test

\begin{tabular}{lccc}
\hline Variabel & & & Ket \\
& Correlation & Sig. & \\
\hline BB Pre & 0.995 & 0.000 & $\mathrm{H}_{0}$ : Ditolak \\
Test * BB & & & \\
Pos Test & & & \\
\hline
\end{tabular}

Berdasarkan hasil uji independen

t-Test menunjukkan nilai sig $(0,000)<$

0,05 H0: ditolak. Artinya terdapat perbedaan yang signifikan berat badan balita pre test dan berat badan balita post test dengan nilai correlation sebesar 0,995.

Selanjutnya untuk mengetahui pemberian makanan tambahan dengan konssep 4 bintang efektif menaikkan berat badan balita dengan gizi buruk di posyandu wilayah puskesmas Ngawen kecamatan Ngawen Kabupaten Klaten maka dilakukan uji hipotesis dengan menggunakan Anava Friedman dan diperoleh hasil sebagai berikut:

Tabel 9

Hasil Uji i Anava Friedman

\begin{tabular}{lcc}
\hline \multicolumn{1}{c}{ Variabel } & Sig. & Ket \\
\hline $\begin{array}{l}\text { BB Pre Test * BB Pos } \\
\text { Test }\end{array}$ & 0.008 & $\mathrm{H}_{0}$ : Ditolak \\
\hline & & \\
\end{tabular}

Berdasarkan hasil uji hipotesis

diatas menunjukkan data bahwa nilai sig $(0.008)<0,05 \quad \mathrm{H}_{0}$ : ditolak artinya pemberian makanan tambahan dengan konssep 4 bintang efektif menaikkan berat badan balita dengan gizi buruk di posyandu wilayah puskesmas Ngawen kecamatan Ngawen Kabupaten Klaten.

\section{PEMBAHASAN}

\section{Karakteristik Responden}

Berdasarkan hasil penelitin karakteristik ibu balita berdasarkan pendapatan menunjukkan responden terbanyak merupakan gakin. Karakteristik ibu balita berdasarkan pendidikan terakhir terbanyak dengan pendidikan terakhir SMA. karakteristik balita berdasarkan jenis kelamin menunjukkan balita terbanyak dengan Janis kelamin perempuan. karakteristik balita berdasarkan usia menunjukkan responden terbanyak dengan usia 21-30 bulan

\section{Berat Badan Balita Pre Test}

Berdasarkan hasil penelitian berat badan balita pre test menunjukkan balita dengan berat 5-6 kg sebanyak 5 responden (28\%), 7-8 kg sebanyak 5 responden (28\%), 9-10 kg sebanyak 6 responden (33\%) dan 11-12 sebanyak 2 responden (11\%) sehingga dapat disimpulkan bahwa responden terbanyak dengan berat 9-10 $\mathrm{kg}$.

\section{Berat Badan Balita Pos Test}

Berdasarkan hasil penelitian berat badan balita pre test menunjukkan balita dengan berat 5-6 kg sebanyak 5 responden (28\%), $7-8 \mathrm{~kg}$ sebanyak 5 responden (28\%), 9-10 kg sebanyak 6 responden (33\%) dan 11-12 sebanyak 2 responden (11\%) sehingga dapat disimpulkan bahwa responden terbanyak dengan berat 9-10 $\mathrm{kg}$.

\section{Pengaruh pemberian makanan tambahan pada balita dengan konsep 4 bintang terhadap kenaikan berat badan pada balita gizi buruk di bulan pertama perlakuan di posyandu puskesmas Ngawen Kecamatan Ngawen Kabupaten Klaten}

Berdasarkan hasil uji independen t-Test menunjukkan nilai sig $(0,000)<$ 0,05 H0: ditolak. Artinya terdapat perbedaan yang signifikan berat badan balita pre test dan berat badan balita post test dengan nilai correlation sebesar 0,995.

Berdasarkan hasil uji hipotesis diatas menunjukkan data bahwa nilai sig 
$(0.008)<0,05 \quad \mathrm{H}_{0}:$ ditolak artinya pemberian makanan tambahan dengan konssep 4 bintang efektif menaikkan berat badan balita dengan gizi buruk di posyandu wilayah puskesmas Ngawen kecamatan Ngawen Kabupaten Klaten

Setiap orang memerlukan 5 kelompok zat gizi (karbohidrat, protein, lemak, vitamin, dan mineral) dalam jumlah cukup, tidak berlebihan dan tidak juga kekurangan, di samping itu, manusia memerlukan air dan serat untuk berbagai proses metabolisme tubuh.

Secara alami, komposisi zat gizi setiap jenis makanan memiliki keunggulan dan kelemahan tertentu. Beberapa makanan mengandung tinggi karbohidrat tetapi kurang vitamin dan mineral. Beberapa makanan lain kaya vitamin $\mathrm{C}$ tetapi miskin vitamin A. Apabila konsumsi makanan sehari-hari kurang beraneka ragam, maka akan timbul ketidakseimbangan antara masukan dan kebutuhan zat gizi yang diperlukan untuk hidup sehat serta produktif. Dengan mengonsumsi makanan sehari-hari yang beranekaragam, kekurangan zat gizi jenis makanan yang satu akan dilengkapi oleh keunggulan susunan zat gizi jenis makanan lain, sehingga diperoleh masukan zat gizi yang seimbang. Jadi, untuk mencapai masukan zat gizi yang seimbang tidak mungkin dipenuhi hanya oleh satu jenis bahan makanan, melainkan harus terdiri atas aneka ragam bahan makanan.

Makanan yang dikonsumsi setiap orang harus memenuhi sumber zat tenaga yaitu padi-padian dan umbi-umbian serta tepung-tepungan, sumber zat pengatur yaitu sayuran dan buah, sumber zat pembangun, yaitu kacang-kacangan, makanan hewani dan hasil olahan. Keseimbangan kecukupan gizi diperoleh apabila hidangan sehari-hari terdiri atas sekaligus kelompok bahan makanan tersebut, jadi apabila balita mengonsumsi beraneka ragam makanan tersebut maka status gizinya akan baik.

\section{KESIMPULAN DAN SARAN}

Simpulan penelitian ini bahwa Pemberian makanan tambahan dengan konssep 4 bintang efektif menaikkan berat badan balita dengan gizi buruk di posyandu wilayah puskesmas Ngawen kecamatan Ngawen Kabupaten Klaten dengan hasil uji hipotesis nilai sig (0.008) $<0,05$. Terdapat perbedaan yang signifikan berat badan balita pre test dan berat badan balita post test dengan nilai correlation sebesar 0,99. Berdasar hasil penelitian dan simpulan bagi tenaga kesehatan khususnya bidan dan petugas gizi. Tenaga kesehatan hususnya bidan dan petugas gizi hendaknya selalu meningkatan pengetahuan ibu balita tentang konsep makan empat bintang bagi balita. Petugas gizi hendakya memberikan buku panduan atau leaflet panduan makan dengan konsep empat bintang.Bagi ibu balita hendaknya dapat memberikan makanan tambahan dengan konsep empat bintang sesuai model yang sudah diberikan dan memberikan makanan sesuai dengan panduan leaflet yng telah diberikan

\section{DAFTAR RUJUKAN}

Depkes RI. 2010. Badan penelitian dan Pengembagan Kesehaan Riset Dasar. Jakarta

Indrawani YM. 2007. Penyakit kurang gizi. Jakarta: Depertemen Gizi dan Kesehatan Masyarakat Fakultas Kesehatan Masyarakat Universitas Indonesia 
200 Jurnal Terpadu Ilmu Kesehatan, Volume 6, No 2,November 2017, hlm 118-240

Istiono W, Suryadi H dkk. 2009. Analisis faktor-faktor yang mempengaruhi status gizi balita. Berita Kedokteran Masyarakat

Khomsan. 2003. Pangan dan gizi untuk kesehatan. Jakarta: PT Raja Grafindo Persada

Suharjo. 2003. Berbagai cara pendidikan gizi. Jakarta: Bumi Aksara

Supariasa, Bakri B dkk. 2012. Penilaian status gizi. Jakarta: EGC

Syarifudin, Hamidah. 2007.Kebidanan komunitas. Jakarta: EGC 